\title{
The Role of Servant Leadership in Church Workers' Commitment
}

Author ORCID: https://orchid.org/0000-0003-0140-7008

Author Affiliation: Seth Akhilele, $\mathrm{PhD}$

SC Classification Genre: Faith-based, Religion, \& Spirituality

Creative Commons Attribution (cc)

Citation: Akhilele, S. (2021) The role of servant leadership in church workers' commitment. Scholar Chatter, 2(3), 14 - 25. http://doi.org/10.47036/SC.2.3.14-25.2021

(C) The Author. 2021. This is an open access publication through Scholar Chatter Society of Academic Publishers.

\begin{abstract}
The study was an examination of the role of servant leadership in worker's commitment to the Xander church (Pseudonym). In Xander church, workers' commitment is shallow, as reflected in attendance and service. A cross-sectional design was used to study 38 workers using nonprobability purposive sampling. The hypotheses were: H1 Is there a statistically significant relationship between servant leader behaviors and workers' commitment? H2: Is there a statistically significant relationship between the servant leadership behavior of empowerment and church workers' reported commitment due to the length of stay? The eight dimensions servant leadership survey instrument measured servant leadership, while workers' commitment was measured with the 15-item Organizational Commitment Questionnaire. The data were analyzed with Spearman's Rho correlation because of a small sample size. The results revealed that servant leadership predicted commitment, and the servant leadership survey element, behavior empowerment, was not predicted by the worker's length of stay. I recommend that further research be conducted to ascertain reasons for a low commitment since servant leadership behavior impacted commitment.
\end{abstract}

Keywords: Servant leadership, commitment, church workers, empowerment, and leadership behavior.

\section{Introduction}

\section{The Role of Servant Leadership in Church Workers' Commitment}

Servant leadership is a multidimensional leadership theory that starts with a desire to serve (Greenleaf, 1998), followed by an intent to lead and develop others (Spears, 2010), and to ultimately achieve a higher purpose objective to the benefit of individuals, organizations, and societies (van Dierendonck, 2017). Although Greenleaf created servant leadership in 1998, its original principles can be found in the Bible (Coetzer et al., 2017). For example, Jesus said, 
You know that those who are regarded as rulers of the Gentiles lord it over them, and their high officials exercise authority over them. Not so with you. Instead, whoever wants to become great among you must be your servant. (King James Bible, 2021, Mark 10:4245).

Servant leadership cuts across a variety of leadership theories (Coetzer et al., 2017). However, it is unique in the sense of its philanthropic characteristics, leadership intent, focus, and other dimensions of leadership attributes. In addition, it focuses on serving people first (Stone et al., 2004). Over the years, servant leadership has developed from its conceptual and philosophical origins in the 1970s to become a theory reinforced by a growing number of stout empirical studies, dependable and valid instruments. Servant leadership has generated considerable attention in recent years (Singfiel, 2017). Practitioners of servant leadership have increased from a trickle to a river during his study (Spears, 2010).

Servant leadership is seen as Jesus' leadership style and His prescription of leadership for intending leaders (Ebener \& O'Connell, 2010; King James Bible, 2021, Matthew 20:27). The servant leader defines the leader's inner nature, character, and spirit, while the leader in servant leader describes the job at hand. A leader makes the intentional effort to influence attitudes, atmosphere, and actions that will bring about change within another person, a group of people, or an organization (Agee, 2001).

Servant leaders possess a special call, and they manifest humility, peace, proclaim a clear vision while attending carefully to those with whom they work. They demonstrate a convincing interior strength not uncommonly displayed through authentic weakness (Holst, 2001). Holst admonished that the entire congregation must be engaged in the servant leadership process, in the heart of a church's renewed mission, with a commitment to change among groups of people as well as within individuals. Examining the impact of servant leadership and transformational leadership in the church, servant leadership demonstrated positive relationships with outcomes such as leader effectiveness, church health perceptions, trust in leader, trust in the organization, follower satisfaction, with marginal support for affective commitment. Moreover, servant leadership independently predicted normative commitment (Scuderi, 2014). Many great preachers provide good sermons, but they do not call for commitment (Warren, 2018). What I aimed to achieve in this study was to demonstrate how servant leadership has impacted church workers' commitment in Xander church since servant leadership has also been researched in the context of the local church (Martin, 2001).

\section{Statement of the Problem, Purpose, and Significance of the Study}

In Xander church, the leaders claimed that church workers' commitment is shallow, as reflected in worship services and serving in the church. There was, therefore, a need to embark on a study to ascertain the reasons for this experience. The purpose of the study was to determine whether servant leadership style impacted workers' commitment. In Shiloh, 5000 committed individuals were studied on its eventual collapse. It was reported that congregants engendered in their priorities and life choices (Goldman, 1995). So, with signs of non-commitment evident in Xander church, it was essential to take this study. Below is the hypotheses for the study: 
Hypothesis 1: Is there a statistically significant relationship between defined servant leader behaviors and workers' commitment?

Hypothesis 2: Is there a statistically significant relationship between the servant leadership behavior of empowerment and church workers' reported commitment due to the length of stay?

\section{Literature Review}

Servant leaders first "make sure that other people's highest priority needs are being served. It has to do with the feelings to serve others first, and the consciousness then results to one aspiring to lead" (Greenleaf, 1977, p. 27). There are 10 characteristics of the servant leader: listening, empathy, healing, awareness, urging, conceptualization, foresight, stewardship, commitment to the growth of people, and building community. The best test of servant leadership would be that those being served would "grow as persons" (Spears, 2010 p. 27) and "become healthier, wiser, freer, more independent, and more likely themselves to turn out to be servants" (Greenleaf, 1977 p. 27).

Servant leadership in the workplace is about helping others accomplish shared objectives by facilitating individual development, empowerment, and collective work consistent with the health and long-term welfare of followers. A servant leader must attend to the needs of followers and help them become healthier, wiser, and more willing to accept their responsibilities. Other roles include nurturing, defending, empowering followers, listening to followers, learning about their needs and aspirations, and being willing to share in their pain and frustration (Yukl, 2013). Another position of the servant leadership theory is that the servant leader must stand for what is good and right, even when it is not in the financial interest of the organization (van Dierendonck, 2017).

Servant leadership has grown remarkably over the last half-century. Though it was primarily considered an intuitive or philosophical approach to leadership for many years, researchers have recently subjected it to stringent quantitative analysis (Singfiel (2017). Research has shown that the servant leadership model is a good way to move ahead in an organization (Bamdale et al., 2017). Servant leadership style possesses increasingly important values where people can achieve power because of their values, ideals, and ethics (Melchar \& Bosco, 2010). It is an approach to leadership with strong altruistic and ethical overtones that asks and requires leaders to be attentive to the needs of their followers and empathize with them; they should take care of them by making sure they become healthier, wiser, freer, and more autonomous so that they too can become servant leaders (Northouse, 2004).

Servant leadership includes the principles of empowerment, team building, total quality, and participating management. (Shekari \& Nikooparvar, 2012). Servant leaders are known for bringing integrity, humility, and servanthood into caring for, empowering, and developing others in carrying out the tasks and processes of visioning, goal setting, leading, modeling, team building, and shared decision-making (Parolini, 2004). 


\section{Servant Leadership in Nonprofits}

Servant leaders demonstrate to the spiritually discerning a convincing interior strength not uncommonly displayed through authentic weakness. Servant leadership can help provide clarity of vision, drive, commitment, and encouragement to congregants. It is a leadership style that one can recommend for the entire congregation(church). At the heart of a church's renewed mission, there must be a commitment to change among groups of people as well as within individuals (Holst, 2001).

The people in a parish with a culture of stewardship (servant leadership) behave as if they are owners of the church in the sense that the church is a precious gift from God. People treat the church like their home. They help each other as a healthy family does. They greet each other, welcome newcomers, and give generously. They also listen, understand, and respond to each other's needs and interests. They contribute to the success of others. They are actively engaged in parish activities. They take their personal development seriously as disciples of Christ (Ebener, 2011).

In work on the leading servant, which employed the story of Saul and his servant, there is a claim that it has many implications for Christian leaders. Every Christian is fundamentally a servant; therefore, every Christian leader is fundamentally a servant. They are only leading servants but leading servants who have a spiritual focus; they seek and expect to find the solution to life's challenges in the providence of God, even in mundane challenges. Leading servants are the ones who find fulfillment in meeting the needs of people. Christian organizations can functionally categorize leaders and followers; both have the same value because both are servants of God who seek to obey their Master's voice. Also, the ministry of leading servants is an ongoing task. Many leaders want to ascend because of their achievements. However, leading servants are content to remain in their original position or go back to their original position after times of unique contribution. Just as Jesus keeps his ministry after his ascension, leading servants continue their ministries until the end of their lives. Christian leadership is exemplified in the leading servant. All the success and failure of the church depends on the understanding and practice of leading servants at every level of the church. Although leading servants' humble attitude makes them seem inferior, they are leaders who draw people to God (Gyeongchun, 2014).

\section{Servant Leadership and Church Workers Commitment}

Commitment is allegiance, a trait of sincerity, steadfastness, dedication. A committed workforce consists of self-motivated staff that can function without supervisory orders and managerial control (Alan, 2011). Allen and Meyer's three-dimensional conceptualization of organizational commitment adapted to team commitment. The dimensions of team commitment are,

1. Affective commitment, which refers to an employee's emotional attachment to, identification with, and involvement in, the team,

2. Continuance commitment, which indicates commitment based on the costs that an employee associates with leaving the team and 
3. Normative commitment, which refers to an employee's feelings of obligation to remain with the team. (Merritt, 2012).

In the world of work, those who sanctify their jobs are more satisfied, more committed to their organization, and at the same time are likely to intend to leave. Sanctification of work is positively related to positive outcomes in job satisfaction, organizational commitment, and intent to leave a job (Walker et al., 2008).

Servant leadership is a better predictor in explaining the attitudes and commitment of service organization members than transformational leadership. While perceptions of transformational leadership and servant leadership styles were highly correlated, servant leadership was identified as a better predictor of the voluntary club members' commitment, satisfaction, and intentions to stay. Club members' perceptions of empowerment mediated the relationship between servant leadership and satisfaction, commitment, and intentions to stay in the volunteer service organizations. Practical implications - Leaders of service clubs may wish to adopt a servant leadership style. These servant leaders may find it practical to provide empowering experiences to encourage volunteers to perform service club activities effectively (Schneider \& George, 2011).

Leaders in nonprofit organizations should implement servant leadership principles and behaviors in their respective organizations, with increased job satisfaction and positive organizational outcomes. A cross-cultural study of the impact of servant leadership also showed that there is a significant relationship between workers and servant leaders. Servant leadership as positively related to followers' self-ratings of psychological capital in both Cambodian and American samples. However, those relationships were more important in the Cambodian setting (Coggins \& Bocarnea, 2015).

\section{Theoretical Framework}

The work of Scuderi was used as a theoretical foundation for the study. It is a study based on servant leadership (Scuderi, 2014). It had to do with the employed Organizational Leadership Assessment (OLA) developed by Laub (2005). The work examined the relative effectiveness of servant leadership and transformational leadership. It sought to provide empirical evidence of each model's independence and unique contributions, as well as their shared contributions. Leaders of church organizations were invited to participate in this survey study, beginning with identifying and assessing servant and transformational leadership styles. Staff members and lay leaders in each church organization later set their pastor's leadership style and leadership effectiveness, in addition to providing evaluations of their church's organizational health. Servant and transformational leadership behaviors were expected to relate positively to the leader, organizational, and follower outcomes (Yukl, 2013). In addition, each leadership style was expected to contribute uniquely to the explanation of leader, organizational, and follower outcomes, supporting the independence of the servant leadership and transformational leadership constructs. These hypothesized relationships were supported by majority of the study variables (Scuderi, 2014).

When considered together, both servant and transformational leadership demonstrated independent, positive relationships with many of the outcomes examined, including leader 
effectiveness, church health perceptions, trust in leader, trust in the organization, and follower satisfaction, with marginal support for affective commitment. Also, servant leadership independently predicted normative commitment, and transformational leadership independently predicted faith maturity, with no significant findings for either predictor on continuance commitment, follower giving, church health statistics, change in church size over time, or change in church finances over time. This study became of great relevance for the study of servant leadership and workers' commitment in Xander church.

\section{Methodology}

I used a survey methodology to study relationships among variables and how attitudes and behavior change over time (Cozby \& Bates, 2015). The appropriate sampling technique for the study was nonprobability purposive sampling, and a quantitative cross-sectional design. The research relied on the research questions generated and lend themselves to investigation using a deductive approach. The study population included all the adults who are workers between the ages of 19 to 70 in Xander church who have been in the church for at least one year. The participants' gender and length of stay were also considered. It is also important to state here that only the workers in Xander church headquarters, Lekki, were considered for this study in 2018. A purposive sampling of 38 workers from Xander church was chosen out of 120 worshipers. The sample size was arrived at using a sample size calculator with a confidence interval of five, a confidence level of $95 \%$, and a population of 142 . These respondents were studied out of the entire population in Xander church due to observed commitment and loyalty apprehensions. Individuals who met the commitment criteria were selected for this study. They could be called the information-rich workers for this research (Patton, 2015).

I used the servant leadership survey (SLS) to study servant leadership and the Organizational Commitment Questionnaire (OCQ) to measure workers' commitment. The instrument for the study is the servant leadership survey for eight behaviors (van Dierendonck $\&$ Nuijten, 2011). The outlined eight dimensions of servant leadership were empowerment, accountability, standing back, humility, authenticity, courage, interpersonal acceptance, and stewardship. The impact of what these behaviors have on each respondent was studied. Questionnaires that reflect the servant leaders' behavior as it impacts church workers' commitment were developed for data collection.

\section{Results}

The Organizational Commitment Questionnaire (OCQ) by Porter and Smith relates to the measurement of affective commitment (Mowday et al., 1979). The 15-item self-report survey asked participants how they agree or disagree with statements that measure their commitment to their organization. Items are scored using a 7-point Likert-type scale. The Cronbach's Alpha values lie between .82 and .93 . The questionnaires were given to the participants and who indicated their responses. The data received were analyzed using non-parametric correlation analysis. Spearman's Rho correlation was used to measure the association between the two variables (servant leadership and workers' commitment). Spearman correlation was preferred for the measurement because of the small sample size of 40 (Williams \& Monge, 2001). 
Participants in the study comprised 40 individuals recruited from Xander church workers from a convenience sample. The population included $47.4 \%$ male and $52.6 \%$ female. Overall, 38 people returned qualifying questionnaires, and two individuals returned incomplete questionnaires. The data from the qualifying questionnaires equated to a $95 \%$ success rate. The tables highlight participant demographics for the 38 participants (see Table 1).

Table 1. Frequency Distribution of Gender Distribution

\begin{tabular}{lcccc}
\hline & $f$ & $\%$ & Valid $\%$ & Cumulative $\%$ \\
\hline Male & 18 & 47.4 & 47.4 & 47.4 \\
Female & 20 & 52.6 & 52.6 & 100.0 \\
Total & 38 & 100.0 & 100.0 & \\
\hline
\end{tabular}

Table 2 provides some important and relevant information, such as the number of participants (N) shown for servant leadership (SL) is 37 , while for commitment (CM)is 38 . In the SPSS analysis, for SL, the mean is 1.5034 , while that of CM is 2.0491 and the standard deviation for SL and CM are 0.37 and 0.29 respectively.

Table 2. Descriptive Statistics of Servant Leadership and Workers' Commitment

\begin{tabular}{lccccc}
\hline & $N$ & Minimum & Maximum & $M$ & $S D$ \\
\hline Age & 38 & 1.00 & 4.00 & 2.4737 & 0.89252 \\
Gender & 38 & 1.00 & 2.00 & 1.5263 & 0.50601 \\
Length & 38 & 1.00 & 3.00 & 2.0789 & 0.78436 \\
SL & 37 & 1.00 & 2.13 & 1.5034 & 0.37672 \\
CM & 38 & 1.13 & 2.67 & 2.0491 & 0.29559 \\
Valid $N$ (listwise) & 37 & & & & \\
\hline
\end{tabular}

Table 3 shows the implication for the Spearman's Rho results. Looking at the significance (2-tailed) value, since the significance (2-tailed) value is less than $0.05, \mathrm{p}=0.031<0.05$; thus, the hypothesis, Is there is a statistically significant relationship between defined servant leader behaviors and workers commitment? is statistically significant. A relationship exists between the role of Xander church servant leadership and workers commitment. This relationship indicates that hypothesis (H1) is supported.

Table 3. The Spearman's Rho Correlations Analysis Results

\begin{tabular}{lcccc}
\hline & & $C M$ & $S L$ \\
\hline Spearman's Rho & CM & Correlation Coefficient & 1.00 & 0.355 \\
& & Sig (2-tailed) & $0.031^{*}$ \\
& $N$ & 38 & 37 \\
& SL & Correlation Coefficient & 0.355 & 1.00 \\
& Sig (2-tailed) & 0.031 & \\
& $N$ & 37 & 37 \\
\hline
\end{tabular}

Note: Correlation is significant at the 0.05 level (2-tailed). 
Table 4 shows that the significance value is greater than $0.05, \mathrm{p}=0.60>0.05$. Thus, the hypothesis, Is there a statistically significant relationship between the servant leadership behavior of empowerment and church workers' reported commitment due to the length of stay? Reveals there is no significant relationship. The hypothesis is not supported, implying the servant leadership behavior, empowerment, does not impact commitment due to length of stay.

Table 4. Spearman's Rho Correlations Analysis Results

\begin{tabular}{|c|c|c|c|c|}
\hline & & & SLI & Length \\
\hline \multirow[t]{6}{*}{ Spearman's Rho } & SLI & Correlation Coefficient & 1.00 & $0.089 *$ \\
\hline & & Sig (2-tailed) & & 0.600 \\
\hline & & $N$ & 37 & 37 \\
\hline & Length & Correlation Coefficient & 0.089 & 1.00 \\
\hline & & Sig (2-tailed) & 0.600 & \\
\hline & & $N$ & 37 & 38 \\
\hline
\end{tabular}

Note: ${ }^{*}$ Correlation is significant at the 0.05 level (2-tailed).

\section{Discussion}

My goal conducting this study was to ascertain a statistically significant relationship between defined servant leader behaviors and workers' commitment. The results indicate that the relationship between servant leadership behaviors and workers' commitment is substantial. This finding agrees with Scuderi (2014), who studied staff members and lay leaders in church organization assessment of their pastor's leadership style and leadership effectiveness and found servant leadership independently predicting normative commitment in the staff members and lay leaders (workers).

Also, I found this study confirming Schneider and George's (2011) work that found servant leadership as a better predictor in explaining the attitudes and commitment of service organization members than transformational leadership. In addition, this study tally with the work of Parris and Peachey, who provided systematic and evidence-based insight into how servant leadership could be a crucial success factor in helping nonprofits. Their results indicated that the founder was a servant leader who influenced volunteer motivation through a shared vision dedicated to helping others, building a caring, loving community, creating the freedom and resources for followers to become servants themselves (Parris \& Peachey, 2013).

On the other hand, the results meant to determine a statistically significant relationship between the servant leadership behavior of empowerment and church workers' reported commitment due to the length of stay showed that the relationship was not significant. This implies that the leader's servant leadership behavior in Xander church to empower workers was not dependent on how long they have stayed in the church. So, one can say that the empowerment part of the leadership behavior is beneficial to every worker irrespective of how long they have worked in Xander church. The result can be displayed to show the nondiscriminatory servant leadership behavior of Xander church leaders. The results revealed that, irrespective of workers' length of stay, they are bound to be empowered to work. 


\section{Limitations of the Study}

The study involved only individuals from Xander church as a solitary church in Lagos. The time available was a constraint to extend the study to more than one church in Lagos and other churches in Nigeria. In the future, scholars might consider extending research to more churches in Nigeria, or beyond, to involve more qualified subjects.

\section{Conclusion}

One can conclude that tremendous and successful organizations consist of leaders and workers. It is, therefore, essential to study the relationship that exists between them. Knowing from this study that servant leadership can predict workers' commitment behavior in the church, the church management should improve all the servant leadership behaviors. The study results will help any church consider what leadership style to adopt to enhance workers' commitment.

Empowerment did not depend on the length of stay of Xander church workers; it is also an excellent lesson for church leaders. However, in solving the research problem of Xander church workers' low commitment, I recommend that further research should focus on discovering what is responsible for employee's length of stay, since the workers are satisfied with the church's servant leadership style.

\section{Funding}

This research was personally funded. There was no external financial assistance. This is one of the reasons why I could not extend the study beyond the headquarters of Xander church.

\section{Acknowledgments}

I want to especially thank the leadership of Xander church for permitting me to conduct this research. Also worthy of appreciation are members of Xander church who gladly contributed to this study as research participants. I am grateful to you all for your support.

\section{References}

Agee, B. R. (2001). Servant leadership as an effective approach to leadership in the church. Southwestern Journal of Theology, 43(3), 7-19.

Alan, P. (2011). Employee engagement. Human Resources Engagement. Cengage learning EMEA $235-253$.

Bamdale, A. J., Girei, A. A., \& Barwa, T. M. (2017). Leadership styles and workers' performance in small and medium scale industries in Adamawa State, Nigeria: A research model. Journal of Economic Development, Management, IT, Finance, and Marketing, 9, 14-23.

Coetzer, M. F., Bussin, M., \& Geldenhuys, M. (2017). The functions of a servant leader. Administrative Sciences, 7(5). https://doi.org/10.3390/admsci7010005 
Coggins, E. D., \& Bocarnea, M. C. (2015). The impact of servant leadership to followers' psychological capital: A Comparative study of evangelical Christian leader-follower relationships in the United States and Cambodia. Journal of Leadership, Accountability, \& Ethics, 12(4), 111-144.

Cozby, P. C., \& Bates, S. (2015). Methods in behavioral research. McGraw-Hill Education.

Ebener, D. R. (2011). Servant leadership and culture of stewardship. Priest, 67(2), 17-21.

Ebener, D. R., \& O'Connell, D. J. (2010). How might servant leadership work? Nonprofit Management and Leadership, 20(3), 315-335. https://doi.org/10.1002/nml.256

Goldman, M. S. (1995). Continuity in Collapse: Departures from Shiloh. Journal for the Scientific Study of Religion, 34(3), 342-353. https://doi.org/10.2307/1386883

Greenleaf, R. (1977). Servant leadership: A journey into the nature of legitimate power and greatness. Paulist Press.

Greenleaf, R. (1998). The power of servant-leadership. Berrett-Koehler Publishers.

Gyeongchun, C. (2014). The leading servant. The Journal of Applied Christian Leadership, $8(1), 8-16$.

Holst, W. A. (2001). Servant leadership for church renewal: shepherds by the living springs. Missiology, 29(2) 248-249. https://doi.org/10.1177/009182960102900235

King James Bible. (2021). www.kingjamesbibleonline.org

Lam, S. S. K. (1998). Test-retest: Reliability of the organizational commitment questionnaire. The Journal of Social Psychology.138(6), 787-788. https://doi.org/10.1080/00224549809603264

Laub, J. (2005). From paternalism to the servant organization: Expanding the organizational leadership assessment (OLA) model. The International Journal of Servant-Leadership; Spokane, 1(1),155-186. https://doi.org/10.1007/978-3-319-77143-4_4

Martin, B. (2001). Transforming a local church congregation through action research, Educational Action Research, 9(2), 261-278, https://doi.org/10.1080/09650790100200152

Melchar, D. E., \& Bosco, S. M. (2010). Achieving high organization performance through servant leadership. The Journal of Business Inquiry, 9(1), 74-88.

Merritt, S. (2012). The two-factor solution to Allen and Meyer's (1990) affective commitment scale: Effects of negatively worded items. Journal of Business \& Psychology, 27(4), 421436. https://doi.org/10.1007/s10869-011-9252-3 
Mowday, R. T., Steers, R. M., \& Porter, L. M. (1979). The measurement of organizational commitment. Journal of Vocational Behavior 14(2), 224-247. https://doi.org/10.1016/0001-8791(79)90072-1

Northouse, P. (2004). Leadership theory and practice (3rd ed.). Sage Publications, Inc.

Parolini, J. L. (2004). Effective servant leadership: A model incorporating servant leadership and he competing values framework. Regent University Servant Leadership Research Roundtable. https://doi.org/10.1108/01437730910949544

Parris, D. L., \& Peachey, J. W. (2013). A systematic literature review of servant leadership theory in organizational contexts. Journal of Business Ethics, 113, 377-393. https://doi.org/10.1007/s10551-012-1322-6

Patton, Q. M. (2015). Qualitative research \& evaluation methods. Sage Publications.

Schneider, S. K., \& George, W. M. (2011). Servant leadership versus transformational leadership in voluntary service organizations. Leadership \& Organization Development Journal, 32(1), 60-77. https://doi.org/10.1108/01437731111099283

Scuderi, N. F. (2011). Servant leadership and transformational leadership in church organizations [Dissertation Notice]. Journal of Applied Christian Leadership, 8(1), 113-113. https://digitalcommons.andrews.edu/cgi/viewcontent.cgi? article $=1226 \&$ context $=\mathrm{jacl}$

Shekari, H., \& Nikooparvar, M. Z. (2012). Promoting Leadership Effectiveness in Organizations: A Case Study on the Involved Factors of Servant Leadership. International Journal of Business Administration, Sciedu Press, 3(1), 54-65.

Singfiel, J. J. (2017). Servant leadership in the Church: The United States and Kosovo in contrast. 5th International OFEL Conference on governance, management, and entrepreneurship. The Paradoxes of Leadership and Governance in the Postmodern Society - Dubrovnik.

Spears, L. C. (2010). Character and servant leadership: Ten characteristics of effective, caring leaders. The Journal of Virtues \& Leadership.1(1), 25-30.

Stone, A. G., Russel, R. F., \& Patterson, K. (2004). Transformational versus servant leadership: A difference in leader focus. Leadership \& Organization Development. Journal, 25, 349361. https://doi.org/10.1108/01437730410538671

van Dierendonck, D. (2017). Servant leadership: A review and synthesis. Journal of Management, 37(4), 1228-1261.https://doi.org/10.1177/01492063310380462

van Dierendonck, D., \& Nuijten, I. (2011). The servant leadership survey: Development and validation of a multidimensional measure. Journal of Business and Psychology, 26, 249267. https://doi.org/10.1007/s10869-010-9194-1 
Walker, A. G., Megan, N., Jones, L., Wuensch, S. A., \& John, G. C. (2008). Sanctifying work: effects on satisfaction, commitment, and intent to leave. The International Journal for the Psychology of Religion, 18(2), 132-145. https://doi.org/10.1080/10508610701879480

Warren, R. (2018). What I learned from Billy: His commitment to the church underscored his desire to model pastoral leadership. Christianity Today, 62(3), 36.

Williams, F., \& Monge, P. (2001). Reasoning with statistics: How to read quantitative research (5th ed.). Thomson Higher Education.

Yukl, G. A. (2013). Leadership in organizations. Pearson Education-Prentice Hall. 